The Effect of Hela Cell Cytoplasm on the Rate of Sedimentation of RNA

Marc Girard, and David Baltimore

PNAS 1966;56;999-1002

doi:10.1073/pnas.56.3.999

This information is current as of December 2006.

E-mail Alerts

Rights \& Permissions

Reprints
This article has been cited by other articles: www.pnas.org\#otherarticles

Receive free email alerts when new articles cite this article - sign up in the box at the top right corner of the article orclick here.

To reproduce this article in part (figures, tables) or in entirety, see:

www.pnas.org/misc/rightperm.shtml

To order reprints, see:

www.pnas.org/misc/reprints.shtml

Notes: 


\title{
THE EFFECT OF HELA CELL CYTOPLASM ON THE RATE OF SEDIMENTATION OF RNA*
}

\author{
By Marc Girard $\dagger$ and David Baltimore \\ SALK INSTITUTE FOR BIOLOGICAL STUdIES, SAN DIEGO, CALIFORNIA
}

Communicated by Renato Dulbecco, July 13, 1966

Ordinarily, sedimentation analysis of RNA preparations is carried out in simple aqueous solutions. Recently, numerous investigators have carried out experiments where RNA's in cytoplasmic extracts from various types of cells have been analyzed by sedimentation through gradients of sucrose. The implicit assumption has been made that the presence of the cytoplasmic extract does not in itself affect the rate of sedimentation of the RNA. However, we have recently found that some component of HeLa cell cytoplasmic extracts causes a 1.5-2-fold increase in the sedimentation rate of a number of species of RNA. Since this result bears on the interpretation of many types of experiments, we will report the phenomenon at this time, even though we know little about its mechanism.

Methods.-Procedures for the preparation of labeled RNA were as described previously. ${ }^{1}$ Briefly, RNA's were prepared from cells by phenol-extraction ${ }^{2}$ and were fractionated on $15-30 \%$ sucrose gradients made with $0.1 \mathrm{M} \mathrm{NaCl}, 0.01 M$ Tris, pH 7.4, and $0.001 M$ EDTA, $0.5 \%$ sodium dodecyl sulfate (SDS-sucrose gradient). Labeled poliovirus RNA was taken from the $35 S$ region of a gradient of the total nucleic acids from actinomycin-treated, infected cells labeled with $\mathrm{P}^{32} \mathrm{O}_{4}$ throughout infection. Poliovirus double-stranded RNA was prepared as previously described. ${ }^{3}$ Labeled HeLa cell messenger RNA was prepared from polyribosomes extracted from cells which had been labeled for 30 min with $\mathrm{H}^{3}$-uridine, ${ }^{4}$ by pooling the $20-35 S$ region of the sucrose gradient. This RNA is free of labeled ribosomal RNA. The $45 S$ ribosomal RNA precursor ${ }^{2}$ was prepared by phenol extraction of the nuclei from cells labeled for $30 \mathrm{~min}$ with $\mathrm{H}^{3}$-uridine. The $16 S$ and $28 S$ species of ribosomal RNA were separated on a sucrose gradient.

Homogenization of cells to produce "cytoplasmic extract" was carried out with an all-glass homogenizer after swelling cells in hypotonic buffer. ${ }^{5}$

Sedimentation coefficients were estimated from the distances of sedimentation in a sucrose gradient, assuming a linear relation between coefficients and distances. ${ }^{6}$ In any one comparison of sedimentation rates, the sucrose gradients were centrifuged together in the same rotor so that the distances sedimented in different tubes are directly comparable. In each rotor at least one tube contained suitable reference markers. The markers used were $74 S$ ribosomes, and the $60 S$ and $45 S$ ribosomal subunits ${ }^{4}$ in gradients centrifuged in $0.0015 M \mathrm{Mg}^{++}$, and $30 S$ and $50 S$ ribosomal subunits in gradients containing 0.02 $M$ EDTA.

The protocol for a typical experiment is as follows: cytoplasmic extract was prepared from $2 \times 10^{7}$ cells in $1 \mathrm{ml}$ of a solution containing $0.01 M$ Tris, $\mathrm{pH} \mathrm{7.4,0.01M} \mathrm{NaCl,} \mathrm{and} 0.0015 M$ $\mathrm{MgCl}_{2}$, kept continually at $0-4^{\circ} \mathrm{C}$. No more than $20 \mu \mathrm{l}$ of a solution of the RNA to be tested (less than $1.0 \mu \mathrm{g}$ ) was added to the extract, which was then rapidly layered on a 15-30\% sucrose gradient made with the same buffer, and was centrifuged for the appropriate time. The temperature was maintained throughout at $0-4^{\circ}$. The gradients were collected, and the radioactivity in each fraction was determined as described previously. ${ }^{5}$ During collection, the absorbance at $260 \mathrm{~m} \mu$ of the effluent was continually monitored. In experiments where $0.02 M$ EDTA was used, the cytoplasmic extracts were adjusted to $0.02 M$ EDTA, and the sucrose solutions for the gradient were made up in $0.02 M$ EDTA, $0.01 M$ Tris, pH 7.4, and $0.01 M \mathrm{NaCl}$.

Results.-Figure 1 compares the rate of sedimentation of $\mathrm{P}^{32}$-labeled poliovirus RNA in $0.0015 M \mathrm{Mg}^{++}$and in a HeLa cell cytoplasmic extract made with 0.0015 $M \mathrm{Mg}^{++}$. Without cytoplasm the RNA sediments at about $50 S ;^{7}$ addition of cytoplasm increases this value to about $75 \mathrm{~S}$. In extracts containing $0.02 M$ EDTA, viral RNA has a sedimentation coefficient of $35 \mathrm{~S}$, and the addition of cytoplasm 


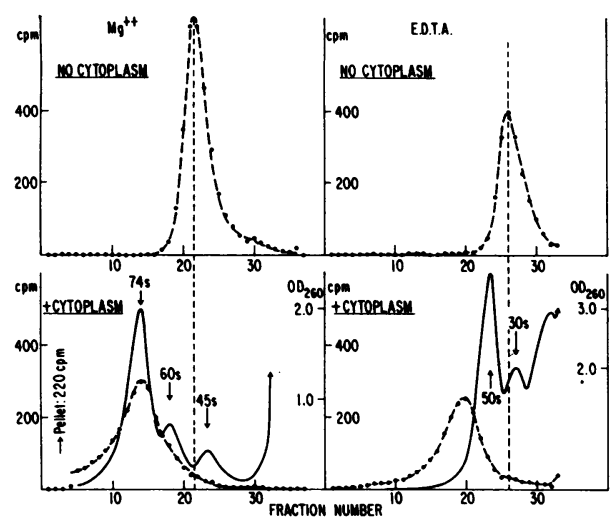

FIG. 1.-Sedimentation of poliovirus RNA. The gradients with $\mathrm{Mg}^{++}$were centrifuged for $16.5 \mathrm{hr}$ at $23,000 \mathrm{rpm}$ in the SW 25.3 rotor of the Spinco ultracentrifuge. The gradients with EDTA were centrifuged $18 \mathrm{hr}$ at 17,000 rpm in the SW 25.1 rotor. In this, and all other figures, the solid line represents optical density at $260 \mathrm{~m} \mu$, and the dotted line is the radioactivity.

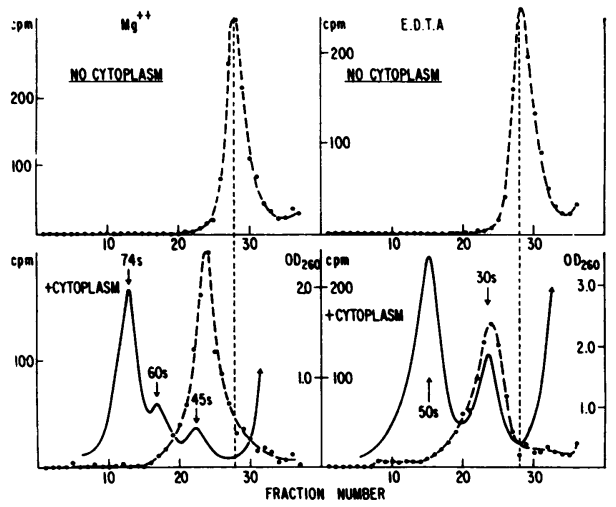

Fig. 2.-Sedimentation of the smaller species of ribosomal RNA. Gradients with $\mathrm{Mg}^{++}$ were centrifuged for $16.5 \mathrm{hr}$ at $23,000 \mathrm{rpm}$ in the SW 25.3 rotor; those with EDTA were centrifuged at $24,000 \mathrm{rpm}$ for $19 \mathrm{hr}$ in the SW 25.1 rotor.

raises this to about $65-70 S$ (Fig. 1). Thus, the increased sedimentation rate in cytoplasm seems to be independent of divalent cations. Extracts from uninfected cells or from poliovirus-infected cells have similar effects.

The effect of cytoplasmic extract on the rate of sedimentation of ribosomal RNA's was also tested, both in the presence of $0.0015 \mathrm{Mg}^{++}$and in $0.02 M$ EDTA. The results with the smaller ribosomal RNA molecule are shown in Figure 2; those obtained with the larger one are shown in Figure 3. Comparing results obtained with and without cytoplasm in a given solution, it can be concluded that:

(1) In $0.0015 \mathrm{M} \mathrm{Mg}^{++}$, the sedimentation rate of the smaller molecule is $30 \mathrm{~S}$ and is increased by cytoplasmic extracts to $45 \mathrm{~S}$; under the same circumstances the larger RNA goes from $40 S$ to $60 \mathrm{~S}$.

(2) In 0.02 $M$ EDTA, the sedimentation rate of the smaller molecule is $16 S$ and is increased by cytoplasmic extract to $30 S$; under these circumstances the larger RNA goes from $28 S$ to $50 S$.

The sedimentation rate of messenger RNA in $0.0015 M \mathrm{Mg}^{++}$is increased by cytoplasmic extract from an average value of $40 \mathrm{~S}$ to an average value of $60 \mathrm{~S}$ (Fig. 4). In 0.02 $M$ EDTA, the sedimentation rate is increased from $25 S$ to about $50 S$ (Fig. 4).

The large, nuclear RNA, which is a precursor of ribosomal $\mathrm{RNA},{ }^{2}$ has a sedimentation rate of $60 S$ in $0.0015 \mathrm{M} \mathrm{Mg}^{++}$, and increases to $100 S$ after addition of cytoplasmic extract. In $0.02 M$ EDTA, the sedimentation rate is increased by the extract from $45 \mathrm{~S}$ to $80 \mathrm{~S}$.

The effect is especially large with double-stranded poliovirus RNA. ${ }^{3}$ In 0.02 $M$ EDTA, this RNA has a sedimentation coefficient of $18 S$ in the absence of cytoplasmic extract, and of $120 \mathrm{~S}$ in its presence. Extracts from either infected or uninfected cells have the same effect.

Because of the large effect on double-stranded RNA, we tested double-stranded 


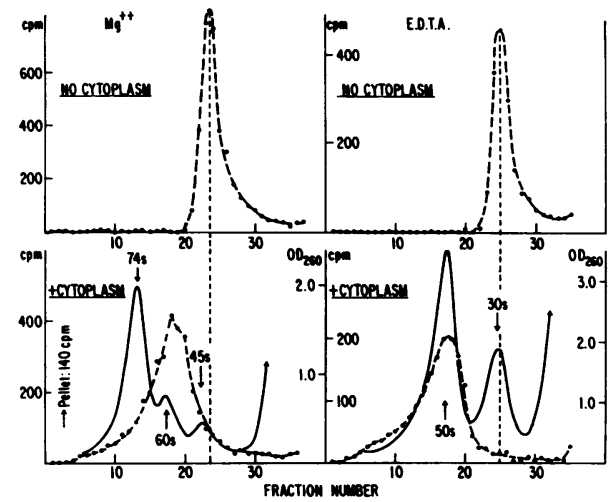

Fig. 3.-Sedimentation of the larger species of ribosomal RNA. Gradients with $\mathrm{Mg}^{++}$ were centrifuged at $23,000 \mathrm{rpm}$ for $16.5 \mathrm{hr}$ in the SW 25.3 rotor; those with EDTA were centrifuged for $19 \mathrm{hr}$ at $22,500 \mathrm{rpm}$ in the SW 25.1 rotor.

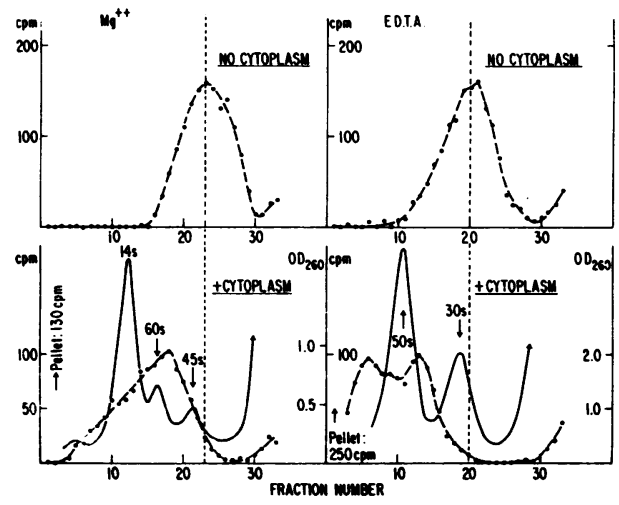

Frg. 4.-Sedimentation of HeLa cell messenger RNA. Gradients were centrifuged in the SW 25.1 rotor for $18 \mathrm{hr}$ at $21,500 \mathrm{rpm}$ $\left(\mathrm{Mg}^{++}\right)$and 25,000 rpm (EDTA).

polyoma DNA (a gift of Dr. Basil Smith) and found that cytoplasmic extract increased its sedimentation rate by a factor of 3 .

In summary, cytoplasmic extract increases the sedimentation rate of singlestranded RNA by a factor of approximately 1.5 in $0.0015 \mathrm{M} \mathrm{Mg}^{++}$, and by a factor of approximately 2.0 in $0.02 M$ EDTA. With double-stranded nucleic acid the effect is even greater.

The factors responsible for the effect of cytoplasmic extract on RNA sedimentation rate are now under study. A few properties are presently known. The fact that the increased sedimentation rate occurs in the presence of EDTA tends to rule out the possibility that it is caused by binding of ribosomes or ribosomal subunits to the RNA. Moreover, we have been able to produce the effect with extracts containing no detectable ribosomal particles. The factors are quantitatively excluded from Sephadex G-50, and thus are probably greater than 10,000 molecular weight. They are present and active whether or not extracts are treated with 1 per cent sodium deoxycholate and 1 per cent Brij (a nonionic detergent).

Discussion.-The fact that cytoplasmic extracts from HeLa cells can increase the sedimentation rate of any kind of added RNA shows that RNA interacts with components of the extracts. It is therefore impossible to know whether in the cytoplasm of intact cells any RNA molecule is free, i.e., not subject to the interaction seen in disrupted cell preparations. The findings also affect the interpretation of experiments in which characteristics of RNA were deduced from its sedimentation rate in cytoplasmic extracts. The following points should be considered.

Attachment of messenger RNA to "subribosomal" particles: It has been reported that vaccinia virus messenger RNA, very soon after its synthesis, becomes attached to the $45 S$ ribosomal subunit. ${ }^{8}$ This conclusion was derived from the observation that newly made messenger RNA sedimented at $45 S$ in cytoplasmic extracts, whereas after extraction from the cytoplasm, it sedimented at $16 S$ in the absence of $\mathrm{Mg}^{++} .9$ As shown above, such an RNA, when simply added to cytoplasmic extract, will sediment at $45 \mathrm{~S}$. Thus, the evidence for an association of newly made 
vaccinia virus messenger RNA with the $45 S$ subribosomal particle vanishes. The same criticism applies to the conclusion that rat liver messenger RNA ${ }^{10}$ and HeLa cell messenger $\mathrm{RNA}^{11}$ become attached to subribosomal particles, and the whole question of how a messenger RNA molecule becomes attached to ribosomes must be reopened. The present results also have some bearing on the interpretation of the structure known as the "informosome". ${ }^{12}$

Existence of subribosomal particles: We showed above that in $0.0015 \mathrm{M} \mathrm{Mg}^{++}$ plus cytoplasmic extract, the two ribosomal RNA species sediment at $45 \mathrm{~S}$ and $60 \mathrm{~S}$, i.e., they have almost exactly the sedimentation rates of the subribosomal particles that are precursors to ribosomes. ${ }^{4}$ This coincidence suggests that the subribosomal particles might actually be spurious products of the interaction of ribosomal RNA with cytoplasmic extract. However, there is evidence that this is not the case. When a mixture of newly made $45 S$ ribosomal precursor particles ${ }^{4}$ and added $16 S$ ribosomal RNA are sedimented together in cytoplasm made in $0.5 \mathrm{M} \mathrm{NaCl}$ plus $0.05 M \mathrm{MgCl}_{2}$, the particles sediment 1.5 times as fast as the added RNA (Girard and Baltimore, unpublished). Thus, the $45 \mathrm{~S}$ ribosomal precursors are distinguishable from added RNA. In any case, the effect of the cytoplasmic extract on the sedimentation rates of the RNA under most conditions must be taken into account in any studies of ribosome formation.

The ribosomal RNA precursor: A precursor of ribosomal RNA with a sedimentation coefficient of $45 \mathrm{~S}$ in SDS-sucrose gradients has been identified. ${ }^{2}$ Since $16 \mathrm{~S}$ ribosomal RNA sediments at $45 S$ in cytoplasm plus $0.0015 \mathrm{M} \mathrm{Mg}^{++}$, the question arises whether the fast sedimentation rate of the nuclear precursor truly reflects a longer length of nucleotide chain than exists in the $16 S$ ribosomal RNA. Since, however, the precursor RNA acts like any single-stranded RNA when added to cytoplasmic extract (i.e., increases further its rate of sedimentation), there is no reason to believe that it is anything other than a long chain of ribonucleotides.

Summary.-Addition of cytoplasmic extract increases the rate of sedimentation of various RNA's (poliovirus RNA, HeLa cell ribosomal RNA, and messenger RNA) by a factor of from 1.5 to 2.0 . The component in the extract which is responsible for this effect has not been identified but appears to be distinguishable from ribosomes.

It is a pleasure to acknowledge the technical assistance of Mr. Stanley Read.

* Supported by grant CA 07592 from the National Cancer Institute, USPHS.

† Fellow of Comité de Biologie Moléculaire, Délégation Générale à la Recherche Scientifique et Technique, Paris, France. Present address: Institut Pasteur, Paris, France.

${ }^{1}$ Baltimore, D., M. Girard, and J. E. Darnell, Virology, 29, 179 (1966).

2 Scherrer, K., and J. E. Darnell, Biophys. Biochem. Res. Commun., 7, 486 (1962).

${ }^{3}$ Baltimore, D., J. Mol. Biol., 18, 421 (1966).

${ }^{4}$ Girard, M., H. Latham, S. Penman, and J. E. Darnell, J. Mol. Biol., 11, 187 (1965).

${ }^{5}$ Penman, S., Y. Becker, and J. E. Darnell, J. Mol. Biol., 8, 541 (1964).

${ }^{6}$ Martin, R. G., and B. N. Ames, J. Biol. Chem., 236, 1372 (1961).

${ }^{7}$ Darnell, J. E., in Basic Mechanisms in Animal Virus Biology, Cold Spring Harbor Symposia on Quantitative Biology, vol. 27 (1962), p. 149.

${ }^{8}$ Joklik, W. K., and Y. Becker, J. Mol. Biol., 13, 511 (1965).

${ }^{9}$ Becker, Y., and W. K. Joklik, these Proceedings, 51, 577 (1964).

${ }^{10}$ Henshaw, E. C., M. Revel, and H. H. Hiatt, J. Mol. Biol., 14, 241 (1965).

${ }^{11}$ McConkey, E. H., and J. M. Hopkins, J. Mol. Biol., 14, 257 (1965).

12 Spirin, A., and M. Nemer, Science, 150, 214 (1965). 